\title{
Peran Media Internet dan Perilaku Terhadap Efektivitas Belajar Mahasiswa Universitas Batanghari (Unbari) di Masa Pandemi Covid-19
}

\author{
Fakhrul Rozi Yamali', Venny Yusiana ${ }^{2}$ \\ ${ }^{1,2}$ Dosen Tetap Universitas Batanghari

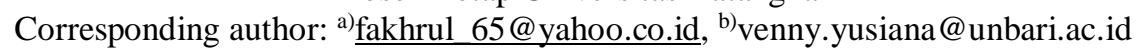

\begin{abstract}
The purpose of this study is to find out and analyze whether there is a role for internet media and together or individually on the teaching effectiveness of Unbari students during the covid-19 pandemic. This reseach focuses on bathches of Unbari student respondents who are active in 2019 and 2020. The method in this research is qualitative with observational analytical methods through the distribution of questionnaires. The framework in this study is based on a cross-sectional study approach with a minimum sample spread for 3 variables as many as 323 respondents. Based on the results of the hypothesis, it is suspected that internet media and behavior together or alone play a role in the learning effectiveness of Unbari students. The results of data analysis based on univariate analysis stated that $50.8 \%$ of respondents stated that online learning was not effective and based on bivariate analysis of internet media and behavior had a significant role on learning effectiveness. Simultaneously, the role of internet media and behavior on the effectiveness of Unbari student learning during the covid-19 pandemic with an $F$ value of 54,526 .
\end{abstract}

Keywords: Internet Media, Behavior, Teaching Effectiveness

\section{Pendahuluan}

Dunia dihebohkan dengan kejadian dahsyat pada tahun 2019 yang membuat masyarakat terhenyak dan resah akibat suatu virus yang terkenal dengan nama virus corona (covid-19), Virus berawal dari Kota Wuhan Tiongkok (Yuliana, 2020). Mulanya virus tersebut tersebar pada pusat grosir di pasar makanan laut yang menjual spesies hewan di daerah Huanan Cina dan sekitarnya dalam waktu yang begitu cepat (Dong et al., 2020). Pada tanggal akhir tahun 2019 terdampak 5 pasien yang dirawat dengan gejala serangan pernapasan mendadak/Syndrome, (Ren L et al., 2020). Peningkatan pasien terdampak virus corona sampai awal januari 2020 begitu cepat sampai mencapai 44 pasien (Susilo et al., 2020). Gejala dan tanda secara umum terkena virus corona-19 yang diantaranya menyerang pernapasan akut seperti batuk-batuk, sesak napas dan demam. Waktu berkembang/ inkubasi dari virus corona-19 sangat cepat antara 5 sampai 6 hari dengan ciri-ciri demam panas, batuk, dan napas tersengal. Negara Kesatuan Republik Indonesia termasuk negara terpadat keempat didunia dan termasuk negara berkembang, sehingga diperediksi akan terdampak sangat lama. Presiden RI Bapak Jokowi dalam pengumumannya untuk pertama kali menyatakan dua kasus terinfeksi virus corona-19 di Indonesia pada 2 Maret 2020. (Djalante et al. 2020). Sampai dengan tanggal 4 Maret 2021, setelah lebih kurang satu tahun total kasus terkonfirmasi 115,76 Juta, sembuh 91,47 Juta dan 2,57 Juta meninggal dari 221 Negara di dunia. Negara Indonesia terkonfirmasi covid-19 sebanyak 1,35 Juta, sembuh 1,17 Juta dan 36,72 ribu meninggal. Provinsi Jambi terkonfirmasi 5.373, sembuh 4.169 dan 82 meninggal dunia.

Terlepas dari beberapa kebijakan yang dikeluarkan pemerintah pusat terkait pembelajaran yang akan dilakukan secara online/daring (dalam jaringan), tentunya tidak bisa dipastikan akan berjalan sesuai dengan harapan pada semua kalangan masyrakat, khususnya untuk mahasiswa yang tinggal dan berada di perdesaan dengan fasilitas yang serba kurang berupa teknologi dalam menunjang proses pembelajaran dalam jaringan, (Brilianur et al, 2020). Aksesibilitas Internet melalui perangkat keras (hardware), perangkat lunak (software) dengan segala kekurangannya, utamanya dari segi pembiayaan yang kurang, untuk meningkatkan sumber daya pada proses belajar di dalam jaringan ini (Yaumi, 2018). Hambatan lainnya pada perkuliahan secara online/dalam jaringan juga dibutuhkan penyesuaian kondisi yang ada dan beberapa media internet yang belum popular bagi mahasiswa. Dampak lain yang dirasakan oleh sebagian mahasiswa adalah beban belajar berupa tugas yang banyak tidak bisa efektif melalui internet yang konektifitas ke komputer belum terintegrasi penuh. Media internet memang bukan hal baru dikalangan mahasiswa namun kendala yang dihadapi dan dirasakan oleh mahasiswa sangatlah banyak, seperti perangkat yang digunakan tidak mendukung. Terhentinya semua aktifitas selama pandemi covid-19 hingga sekarang belum juga berakhir dan tentunya menimbulkan banyak perubahan yang dirasakan dan beban biaya yang lebih sebagai konsekuensi dari belajar secara online/dalam jaringan ini. Minimnya biaya dan semua fasilitas yang memadai membuat proses pembelajaran online tidak akan efektiv seperti yang diharapkan. Penomena baru timbul selama pandemi covid-19 dari efektivitas kegiatan belajar mahasiswa Universitas Batanghari seperti kosongnya area olahraga, ruang baca perpustakaan, posko mahasiswa seperti UKM dan lain-lain. Perubahan perilaku yang kelihatan jelas dan sangat signifikan dari cara menjaga kesehatan dari semua individu tidak terkecuali dari kedisiplinan mahasiswa dalam penggunaan masker, mencuci tangan dan menjaga jarak pada semua aktivitas. Perilaku mahasiswa akibat dampak covid-19 sampai saat ini 
akan diberlakukan kuliah secara campuran dengan pembatasan pada pola belajar, interaksi sosial baik menggunakan media atau secara konvensional dan keinginan hidup sehat merupakan bagian dari pola baru. Perubahan mendasar pada proses belajar mengajar yang terjadi dimasa pandemi covid-19 ini mengakibatkan metode belajar mengajar online/ dalam jaringan yang mendapatkan berbagai reaksi dari hampir semua mahasiswa. Hasil dari analisis pada penelitian ini diharapkan untuk mengetahui: Peran media internet dan perilaku terhadap efektivitas belajar mahasiswa UNBARI di masa pandemi covid-19

\section{Kajian Literatur}

Pembelajaran daring atau E-Learning adalah metode dalam pembelajaran yang berbasis internet yang mesti dijalani oleh siswa-siswi sampai mahasiswa-mahasiswi di Republik Indonesia juga negara negara didunia yang terdampak pandemi covid-19, untuk melaksanakan proses belajar mengajar secara langsung dengan tatap muka di kelas pastinya terkendala akibat diharuskannya menjaga jarak untuk tidak berkerumun atau berkumpul dalam rangka mencegah meluasnya virus corona-19. Di Indonesia cara belajar online tidak lagi menjadi barang baru baru, namun masih ada lembaga pendidikan yang belum siap melakukan belajar secara online/ dalam jaringan ini, utamanya pada lembaga pendidikan yang berada didaerah terpencil atau terisolir. (Briliannur et al, 2020). Dengan kemajuan teknologi saat ini memungkinkan mahasiswa dapat belajar secara online sambil tetap berintekrasi dengan teman sekelas, berdiskusi tentang mata kuliah terkhusus mata kuliah yang sedang berlangsung, melalui konferensi video, dokumen, digital, dan lain-lainya. Sarana dan prasarana yang digunakan seperti smartphone, laptop/ computer dengan berbagai aplikasi dan tentunya jaringan internet yang digunakan sebagai media dalam belajar mengajar online/dalam jaringan. Karena perekonomian yang tidak merata membuat belajar online/ dalam jaringan tidak bisa dilaksanakan dengan sempurna dan tentunya masih perlu dicarikan bagaimana jalan keluarnya. Berbagai kebijakan diterapkan oleh pemerintah untuk menghindari meluasnya penyebaran virus corona-19 seperti meliburkan untuk sementara lembaga pendiddikan mulai dari pendidikan dasar sampai pendidikan tinggi dan semua fasilitasnya dalam waktu tidak tertentu sehingga timbul masalah baru dalam proses belajar akibat dari di terapkannya belajar online/dalam jaringan yang harus didukung oleh teknologi digital, dampak yang paling dirasakan pastinya terasa oleh mahasiswa yang tinggal di daerah dengan semua keterbatasan fasilitas pendukungnya.

\section{Peran Media Internet terhadap Efektivitas Belajar}

Media merupakan alat komunikasi sebagai efektivitas belajar yang berupa media internet dan media konvensional dengan aktivitas kolektif, terutama pada area penggunaan publik, diantarnya berita, aplikasi belajar, forum dan diskusi, pencarian informasi, serta potensi pembentukan komunitas tertentu. Wati (2012) dalam penelitiannya menyatakan, Internet adalah media komunikasi juga informasi yang melibatkan setiap pengguna untuk bisa berpartisipasi di segala waktu. Internet adalah suatu jaringan informasi dari komputer yang terhubung sebagai alat komunikasi yang menghubungkan dari satu tempat ke tempat yang lain dan digunakan sebagai bentuk sumber dan media bagi semua pengetahuan. Penentuan dalam media pembelajaran teknologi yang berbasis internet benar-benar harus penuh pertimbangan, dan jika tidak tepat sasaran bisa berdampak buruk pada hasil belajar. Efektivitas teknologi yang berbasis digital harus benar-benar di pahami oleh pendidik secara prinsif dan peran faktornya dalam proses belajar mengajar (Putrawangsa \& Hasanah, 2018). Pada masa kuliah secara online/ dalam jaringan, internet merupakan salah satu andalan bagi mahasiswa dalam mengikuti dan mencari sumber pengetahuan guna mendukung pencapaian materi dalam perkuliahan. Belajar mengajar melalui online tidak terlepas dari penggunaan jaringan internet. Pada saat belajar online sedang berlangsung, biasanya yang sering dihadapi mahasiswa dengan permasalahan jaringan internet yang kurang mendukung. Belajar online/dalam jaringan masih kurang efektiv dikarenakan terkendala kuota yang dimiliki serta dukungan jaringan internet yang tidak kuat, sehingga sering kali lose connecting pada saat belajar sedang berlangsung yang bisa berakibat tertinggalnya materi yang diterima dan lainnya, (Ningsih dan Rahadi, 2020).

\section{Peran Perilaku terhadap Efektivitas Belajar}

Perilaku mempunyai dua arti penting secara luas dan sempit, 1). Perilaku dalam artian luas ialah sebagai sesuatu yang dialami seseorang. 2). Perilaku dalam artian sempit ialah semua yang mencakup semua reaksi yang dapat dilihat. Perilaku luas akibat dari dampak covid-19 terlihat dari perilaku baru dalam menjaga kesehatan dengan keteraturan memakai/ menggunakan masker, mencuci tangan juga menjaga jarak. Sedangkan perilaku sempit dalam pembelajaran adalah kosongnya area olah raga, ruang baca perpustakaan, posko mahasiswa seperti UKM dan lainlain. Efektivitas dalam pembelajaran bisa tercapai diantaranya dengan menggunakan media pembelajaran untuk proses pembelajaran disesuaikan dengan keadaan juga situasi sekarang, baik dilihat dari konten maupun materi, perilaku maupun keadaan 


\section{Peran Media Internet dan peran perilaku terhadap Efektivitas Belajar.}

Penggunaan teknologi komputer melalui akses internet guna menyediakan informasi, bahan-bahan bacaan dan materi-materi kuliah untuk para mahasiswa. Interaksi berkomunikasi dari satu tempat ke tempat yang lain pada waktu yang sama dan dilokasi yang berbeda dengan penggunaan fasilitas teknologi internet. Media merupakan alat komunikasi sebagai efektivitas belajar yang berupa media internet dan media konvensional dengan aktivitas kolektif, terutama pada area penggunaan publik, diantarnya berita, aplikasi belajar, forum dan diskusi, pencarian informasi, serta potensi pembentukan komunitas tertentu. Efektiv bisa diartikan kemampuan mencapai suatu tujuan yang sudah di tetapkan seperti efektivitas dalam pemanfaatan media online pada proses pengajaran. Media dalam pembelajaran secara online merupakan bagian dari bentuk pembelajaran yang diharapkan tersampaikannya materi bahan ajar melalui pemanfaatan fasilitas internet. Pembelajaran dikatakan efektiv terlihat dari aktivitas siswa sewaktu belajar mengajar dilangsungkan, terlihat dari perilaku perilaku siswa dalam belajar dan menguasai konsep. Pembelajaran yang efektiv dan efisien dicapai dengan hubungan bolak balik antara guru dan murid guna mencapai tujuan bersama, juga harus menyesuaikan sekitar seperti lingkungan, sarana dan prasarana yang ada, serta fasilitas media pembelajaran yang digunakan guna membantu tercapainya aspek perkembangan siswa (Syarifudin, 2020). Akibat pandemi virus corona-19, membuat seluruh lembaga pendidikan mulai dari pendidikan dasar dasar sampai pendidikan tinggi secara mendadak dalam waktu yang begitu cepat harus menyiapkan diri dan mengikuti perkembangan pada penggunaan media online/dalam jaringan, namun pemanfaatan teknologi digital dan media online, metode dalam jaringan justru membuat masalah baru yang bisa menghambat dalam terlaksananya efektivitas pembelajaran, keterbatasan penyediaan biaya dan perilaku yang kurang baik membuat terhambatnya proses, sarana prasarana, jaringan internet, akibatnya penguasaan teknologi informasi pengajar maupun peserta didik terkendala. (Rizqon, 2020).

\section{Metode}

Metode dalam penelitian ini ialah bersifat kuantitatif dengan metode analitik observasional melalui penyebaran kuesioner kepada 323 mahasiswa angkatan 2019 dan angkatan 2020 sebagai responden. Kerangka dalam penelitian ini berupa pendekatan cross sectional study, suatu penelitian yang mengukur beberapa variabel penelitian dalam satu saat dan satu waktu sekaligus (Notoatmodjo, 2005). Objek dari penelitian yang akan menjadi variabel bebas adalah Media Internet dan Perilaku, sedangkan yang akan menjadi variabel terikat ialah Efektivitas Belajar. Analisis univariat digunakan pada variabel tunggal dan dilakukan guna menampilkan dan melaksanakan tabel pada distribusi frekuensi dari variabel variabel independen dan variabel dependen (Sudigdo dan Sofyan, 2011). Untuk mengetahui gambaran dari distribusi frekuensi juga proporsi yang sedang ditelaah digunakan analisis ini. Analisis bivariate yang akan dipakai guna melihat peran antar variabel variabel independen dengan variabel dependen, adapun Uji statistik yang dipakai adalah Uji Chi Square. Batas kemaknaan yang akan dipakai pada penelitian ini yaitu nilai $\alpha$ 0,05 . Pengambilan dalam keputusan statistik dilakukan dengan cara membandingkan nilai $p$ ( $p$ value) dengan nilai $\alpha$ $(0,05)$, melalui ketentuan tersebut. (Hastono, 2001). Dalam penelitian ini uji F dipakai untuk mengetahui apakah ada peran media internet dan perilaku secara bersama-sama/simultan terhadap efektivitas belajar mahasiswa Unbari di masa pandemi covid-19.

\section{Hasil}

Berdasarkan distribusi frekuensi responden yang diurut dari jenis kelamin didapat bahwa sebagian besar responden pada penelitian ini berjenis kelamin laki-laki yaitu sebanyak 166 responden $(51,4 \%)$, dan berdasarkan umur dapat diketahui bahwa sebagian besar umur responden pada penelitian ini yaitu berumur kurang dari 20 tahun (77,1\%), berdasarankan fakultas dari lima fakultas yang ada di Unbari bahwa sebagian besar responden pada penelitian ini yaitu dari fakultas hukum sebanyak $43 \%$, fakultas teknik 18,6\%, fakultas 15,8\%, fakultas ekonomi $13,3 \%$ dan sisanya sebesar 9,3\% dari fakultas kejuruan dan ilmu pendidikan.

Penggunaan media daring berdasarakan aplikasi terbesar didominasi oleh Google Class Room sebesar 74\%, Whatsapp $21,7 \%$ dan sisanya 4,3\% menggunakan aplikasi Zoom Meeting. Kategori tempat pelaksanaan daring didominasi kebanyakan dilakukan di rumah sebesar 97,8\% dan sisanya 2,2\% dilakukan di kampus. Distribusi koneksi internet penggunaan Internet Selular masih mendominasi sebesar 79,6\% hingga sisanya sebesar 20,4\% dengan koneksi Wifi. Frekuensi berdasarkan kuota internet 44,3\% didominasi kuota internet 100-200k, 35,6\% kuota internet kurang dari 100k dan sisanya sebesar 20\% kuota internet lebih dari 200k. Distribusi Frekuensi berdasarkan variabel media internet mendukung dalam pembelajaran secara daring didominasi sebesar 51,4\% dan sisanya sebesar 48,8\% tidak mendukung. Berdasarkan varibel perilaku sebesar $69 \%$ perilaku mahasiswa kurang baik dan sisanya sebesar $31 \%$ peilaku mahasiswa baik dalam mendukung proses belajar secara daring. Berdasarakan variabel efektivitas sebesar $50,8 \%$ responden menyatakan tidak efektif dan sisanya sebesar 49,2\% efektif dalam pembelajaran daring selama pandemic covid-19. Guna melihat hubungan kemaknaan antara variabel-variabel bebas/independen (media internet dan perilaku) dengan variabel terikat / dependen (efektivitas belajar). Alat analisis statistik yang digunakan adalah $U j i$ 
Fakhrul Rozi Yamali dan Venny Yusiana, Peran Media Internet dan Perilaku Terhadap Efektivitas Belajar Mahasiswa Universitas Batanghari (Unbari) di Masa Pandemi Covid-19

Chi-Square. Adapun batas kemaknaan yang akan diukur didalam adalah nilai $\alpha 0,05$. Sehingga pengambilan keputusan berdasarkan uji statistik dilakukan dengan membandingkan nilai $p(p$ value) dengan nilai $\alpha(0,05)$.

Tabel 1

Peran Media Internet Terhadap Efektivitas Belajar Mahasiwa Universitas Batanghari (Unbari) di Masa Pandemic Covid19

\begin{tabular}{|c|c|c|c|c|c|c|c|}
\hline \multirow{3}{*}{ Media Internet } & \multicolumn{4}{|c|}{ Efektivitas Belajar } & \multirow{2}{*}{ Total } & \multirow{3}{*}{$p$-value } & \multirow{3}{*}{$\begin{array}{c}\text { OR } \\
95 \% \mathrm{CI}\end{array}$} \\
\hline & \multicolumn{2}{|c|}{ Kurang Efektif } & \multicolumn{2}{|c|}{ Efektif } & & & \\
\hline & $\mathrm{N}$ & $\%$ & $\mathrm{~N}$ & $\%$ & $\mathrm{~N}$ & & \\
\hline Tidak Mendukung & 116 & 73,9 & 41 & 26,1 & 157 & 0,000 & $6,955(4,264-11,345)$ \\
\hline Mendukung & 48 & 28,9 & 118 & 71,1 & 166 & & \\
\hline
\end{tabular}

Sumber: data olahan

Hasil uji statistik analisis bivariat pada tabel saji di atas menunjukkan media internet memiliki peran yang signifikan terhadap efektivitas belajar mahasiswa Unbari pada masa pandemic covid-19, yaitu dengan nilai $p$ value 0,000 ( $p$-value kurang dari 0,05); dari 323 responden, 166 orang responden menyatakan media internet sangat mendukung dalam efektivitas belajar. Diketahui bahwa proporsi terbesar dalam pengaruhnya terhadap kurang efektivnya belajar mahasiswa pada masa pandemic covid-19 yaitu media internet yang tidak mendukung, yaitu sebesar 73,9\%. Hasil dari statistik lain pada tabel saji di atas menampilkan nilai OR lebih dari 1, yang mempunyai arti bahwa media internet yang tidak mendukung merupakan faktor risiko atau mampu meningkatkan risiko efektivitas belajar yang kurang efektiv sebesar 6,955 kali dibandingkan media internet yang mendukung $(\mathrm{OR}=6,955,95 \%$ CI 4,264$11,345)$.

Tabel 2

Peran Perilaku Terhadap Efektivitas belajar Mahasiwa Unbari di Masa Pandemic Covid-19

\begin{tabular}{|c|c|c|c|c|c|c|c|}
\hline \multirow{3}{*}{ Perilaku } & \multicolumn{4}{|c|}{ Efektivitas Belajar } & \multirow{2}{*}{ Total } & \multirow{3}{*}{ p-value } & \multirow{3}{*}{$\begin{array}{c}\text { OR } \\
95 \% \mathrm{CI}\end{array}$} \\
\hline & \multicolumn{2}{|c|}{ Kurang Efektif } & \multicolumn{2}{|c|}{ Efektif } & & & \\
\hline & $\mathrm{N}$ & $\%$ & $\mathrm{~N}$ & $\%$ & $\mathrm{~N}$ & & \\
\hline Kurang Baik & 140 & 62,8 & 83 & 37,2 & 223 & 0,000 & $5,431(3,134-9,104)$ \\
\hline Baik & 24 & 24 & 76 & 76 & 100 & & \\
\hline
\end{tabular}

Sumber: data olahan

Hasil uji statistik analisis bivariat pada tabel saji di atas menunjukkan bahwa perilaku memiliki hubungan yang signifikan dengan efektivitas belajar mahasiswa Unbari pada masa pandemic covid-19, yaitu dengan nilai $p$ value 0,000 (p-valuekurang dari 0,05). Diketahui bahwa perilaku yang baik merupakan proporsi terbesar dalam pengaruhnya terhadap efektivitas belajar yang baik, sebesar 76\%. Hasil statistik lainnya dari tabel saji di atas menampilkan nilai OR lebih dari 1, yang mempunyai arti bahwa perilaku yang kurang baik merupakan faktor risiko atau mampu meningkatkan risiko efektivitas belajar yang kurang baik sebesar 5,431 kali dibandingkan perilaku yang baik $(\mathrm{OR}=5,431,95 \%$ CI 3,134-9,104).

Tabel 3

Uji F

\begin{tabular}{|l|l|r|r|r|r|r|r|}
\hline \multicolumn{2}{|c|}{ Model } & Sum of Squares & Df & Mean Square & \multicolumn{1}{c|}{ F } & \multicolumn{1}{c|}{ Sig. } \\
\hline 1 & Regression & 20.519 & 2 & 10.260 & 54.526 & $.000^{\mathrm{b}}$ \\
\cline { 2 - 9 } & Residual & 60.212 & 320 & .188 & & \\
\cline { 2 - 9 } & Total & 80.731 & 322 & & & \\
\end{tabular}

Sumber: data olahan

Kriteria pegujian dalam hipotesis pada penggunaan uji $\mathrm{F}$ adalah bila nilai signifikan $\mathrm{F}$ kurang dari 0.05 maka hipotesis diterima, yang menyatakan bahwa semua variabel independen secara simultan mempunyai peran terhadap variabel dependen (Ghozali, 2016). Dari hasil uji $\mathrm{F}$ diketahui bahwa nilai $\mathrm{F}$ hitung sebesar 54,526 lebih dari $\mathrm{F}_{\text {tabel }}$ 0,331 dengan tingkat signifikansi 0,000 atau kurang dari 0,05, maka dapat dikatakan bahwa terdapat peran media internet dan peran perilaku secara simultan terhadap efektivitas belajar mahasiswa Unbari dimasa pandemi covid-19.

\section{Peran Media Internet Terhadap Efektivitas belajar Mahasiwa UNBARI di Masa Pandemic Covid-19}

Hasil penelitian menunjukkan bahwa media internet memiliki peran yang signifikan terhadap efektivitas belajar mahasiswa Unbari pada masa pandemic covid-19, yaitu dengan nilai p value 0,000 ( $p$-value kurang dari 0,05). Dari 323 responden, 166 orang responden menyatakan peran media internet sangat berperan dalam efektivitas belajar. 
Diketahui bahwa proporsi terbesar dalam perannya terhadap tidak efektifnya belajar mahasiswa pada masa pandemic covid-19 yaitu media internet yang tidak mendukung, yaitu sebesar 73,9\%. Sejalan dengan hasil penelitian yang dilakukan oleh Isdhana (2011) bahwa mahasiswa menggunakan media internet sebagai sumber untuk belajar, karena dengan media internet dapat memudahkan dalam mencari informasi seperti tugas-tugas mata kuliah. Zhang et al. (2004), menyatakan penyampaian pengetahuan dari kelas tradisional kekelas online/dalam jaringan mampu dirubah dengan penggunaan internet dan teknologi multimedia. Berdasarkan penelitian Ningsih et al. (2020) menunjukkan bahwa sebagian mahasiswa lebih menyukai pembelajaran secara offline dibandingkan pembelajaran daring sebesar 93,5\%, hasil penelitiannya sama dengan hasil yang dilakukan oleh peneliti yaitu sebesar 56,9\% mahasiswa menyukai pembelajaran secara offline. Hal tersebut terjadi karena keterbatasan sinyal internet yang kurang stabil yang berdampak pada kurangnya pemahaman mahasiwa/mahasiwi pada materi perkuliahan yang telah disampaikan oleh dosen. Keterbatasan didalam aksesibilitas Internet, hardware maupun software, juga pembiayaan yang sering menjadi masalah didalam memaksimalkan belajar secara online/dalam jaringan (Yaumi, 2018). Pada saat ini untuk dapat keluar dari krisis pandemic covid-19 diperlukannya transformasi mengenai pembelajaran dan kerjasama antar pendidikan tinggi. Pada proses pembelajaran jarak jauh, pemanfaatan virtual learning diharapkan dapat memberikan kemudahan-kemudahan belajar, bisa menjadi sarana untuk bisa berkomunikasi secara langsung melalui dunia maya, juga menghindari kontak fisik langsung agar mencegah penularan covid-19 (Mashuri, 2020). Diharapkan untuk belajar secara online yang bukan sekedar dijadikan sebagai manfaat lebih (Williams, Birch, \& Hancock, 2012). Harapan dari para ahli untuk terus mengarahkan dengan segala kemampuan terselenggaranya pendidikan online yang akan dijadikan tujuan yang akan di capai pada tahun 2025 (Palvia, et al., 2018). Media internet bisa dapat digunakan mempermudah dan mendapatkan pengetahuan bagi mahasiswa mencari kebutuhan informasi terbaru.

\section{Peran Perilaku Terhadap Efektivitas belajar Mahasiwa UNBARI di Masa Pandemic Covid-19}

Hasil penelitian diketahui bahwa perilaku mempunyai peran yang signifikan terhadap efektivitas belajar mahasiswa UNBARI pada masa pandemic covid-19, yaitu dengan nilai $p$ value 0,000 ( $p$-value kurang dari 0,05 ). Diketahui bahwa perilaku mahasiswa yang baik merupakan proporsi terbesar dalam pengaruhnya terhadap efektivitas belajar yang baik, sebesar 76\%. Hasil statistik dari tabel saji di atas menampilkan nilai OR > 1, artinya bahwa perilaku yang kurang baik merupakan faktor risiko atau mampu meningkatkan risiko efektivitas belajar yang kurang baik sebesar 5,431 kali dibandingkan perilaku yang baik ( $\mathrm{OR}=5,431,95 \%$ CI 3,134-9,104). Pembelajaran daring akibat pandemi covid-19 ini sangat berperan terhadap perilaku mahasiswa, yaitu mahasiswa yang walaupun aktif mengikuti pelajaran secara daring, akan tetapi pada hakekatnya merasakan bosan dengan keadaan seperti itu (Widagdo et al, 2020). Menurut penelitian, Briliannur. (2020) menghasilkan kegiatan yang sama pada belajar mengajar yang dilakukan secara online, banyak dari murid merasa jenuh dan hal ini akan mempengaruhi keefektifan hasil belajar anak didik. Pandemi covid-19 memberikan dampak kuat bagi mahasiswa, akibat dari kondisi seperti sekarang ini mahasiswa menghabiskan banyak waktu pada media sosial dan HP. Dengan demikian, mahasiswa tersebut mengalami keterbatasan pada interaksi di lingkungan kampus dan kawan-kawan sehingga menjadikan mahasiswa tersebut banyak melakukan interaksi dengan media sosial lainnya melalui handphone (Widagdo et al, 2020). Efek dari penggunaan handphone pada media sosial yang sering atau berkelanjutan di masa pandemi dapat berdampak negatif sehingga diharapkan peran orang tua dalam mendidik dan mengawasi perilaku anak pada masa pandemi ini.

\section{Peran media internet dan perilaku secara bersama-sama terhadap efektivitas belajar dimasa covid-19}

Proses pembelajaran daring atau online merupakan pembelajaran yang dilakukan dengan jarak jauh menggunakan internet tentukan tidak terlepas dari sinyal dan jaringan untuk bisa saling terhubung satu sama lain antara mahasiswa dengan dosen. Masalah yang sering timbul adalah jaringan internet di saat pembelajaran secara daring sedang berlangsung. Oleh sebab itu pembelajaran secara daring masih kurang efektiv karena terkendala kuota yang masih terbatas serta jaringan yang masih kurang stabil. Minimnya komunikasi menyebabkan pada saat pembelajaran sedang berlangsung bisa berdampak pada pemahaman materi yang diberikan dan lainnya sebagainya. (Fauzan, 2021). Sejalan juga dengan hasil penelitian yang dilakukan peneliti bahwa sebanyak 50,8\% responden dalam pembelajaran daring selama pandemic covid-19 saat ini menyatakan tidak efektiv. Sementara uji F didapatkan hasil nilai $F_{\text {hitung }}$ sebesar 54,526 lebih dari $F_{\text {tabel }} 0,331$ dengan tingkat signifikansi 0,000 atau kurang dari 0,05, maka dapat dikatakan juga terdapat peran media internet dan peran perilaku secara simultan dan signifikan berperan terhadap efektivitas belajar mahasiswa Unbari dimasa pandemi covid-19. Namun, terdapat penelitian lain yang menujukan pembelajaran secara daring terbukti efektiv dilakukan pada masa WFH (Darmalaksana et al, 2020). Keadaan ini juga dialami pada sistem pendidikan yang berada di Georgia di saat semester musim semi awal tahun 2020 mengalami perubahan. Georgia merupakan satu dari 188 negara dibelahan dunia yang menangguhkan proses pendidikan secara tatap muka. Pemerintah Georgia sangat mendukung masyarakatnya untuk segera beradaptasi pada teknologi baru yang di implentasikan dengan memberikan bantuan pada penggunaan berbagai aplikasi internet yang ada, agar pendidikan 
Fakhrul Rozi Yamali dan Venny Yusiana, Peran Media Internet dan Perilaku Terhadap Efektivitas Belajar Mahasiswa Universitas Batanghari (Unbari) di Masa Pandemi Covid-19

dalam jaringan berhasil dan bisa berlanjut untuk kemajuan masa yang akan datang (Giorgi Basilaia \& David Kvavadz, 2020)

\section{Simpulan}

1. Terdapat peran media internet yang sangat besar terhadap efektivitas belajar mahasiswa UNBARI, proporsi terbesar dalam pengaruhnya terhadap kurang baiknya efektifitas belajar mahasiswa di masa pandemic covid- 19 yaitu media internet yang tidak mendukung sebesar $73,9 \%$.

2. Terdapat peran perilaku yang sangat besar terhadap efektivitas belajar mahasiswa UNBARI, proporsi terbesar dalam pengaruhnya terhadap efektifitas belajar yang baik sebesar 76\% di masa pandemi covid- 19 .

3. Terdapat peran media internet dan peran perilaku secara signifikan dan simultan berperan terhadap efektivitas belajar mahasiswa UNBARI, indikasinya adalah 50,8\% menyatakan pembelajaran dalam jaringan selama pandemi covid-19 saat ini belum efektif.

\section{Daftar Pustaka}

Briliannur, D.C., at.al (2020). Analisis Keefektifan Pembelajaran Online di Masa Pandemi Covid-19. Jurnal Pendidikan Guru Sekolah Dasar, E-ISSN 2721-7957, 28-37.

Darmalaksana, W., at.al (2020). Analisis Pembelajaran Online Masa WFH Pandemic Covid-19 sebagai Tantangan Pemimpin Digital Abad 21. pp.1-12.

Djalante R, at.al (2020). Review and Analysis of Current Responses to Covid-19 in Indonesia: Period of January to March 2020. Progress in Disaster Science, 100091, 1-9.

Dong Y, Mo X, Hu Y, et al. (2020). Epidemiology of Covid-19 Among Children in China. American Academy of Pediatrics, DOI: 10.1542/peds.2020-0702

Fauzan, M., 2021. Perilaku Mahasiswa dalam Melaksanakan Pembelajaran Daring di Masa Pandemi. Jurnal Perilaku dan Strategi Bisnis. 9(1), 61-70.

Giorgi Basilaia, David Kvavadze., Transition to Online Education in Schools during a SARS-CoV-2 Coronavirus (COVID-19) Pandemic in Georgia. Pedagogical Research, April 2020. https://doi.org/10.29333/pr/7937.

Mashuri H., 2020. Pembelajaran Di Masa Covid-19 Work From Home. Dwiyogo WD, editor. Malang: Wineka Media Anggota; 2020. 66 p.

Ningsih, I. P., \& Rahadi, D. R. (2020). Perilaku Mahasiswa Terhadap Pembelajaran Daring di Maasa Pandemi Covid19. Jurnal Manajemen Bisnis (JMB), 102-108.

Notoatmodjo, Soekidjo., (2007). Metodologi Penelitian Kesehatan (Edisi Revisi), Jakarta:Rineka Cipta. Jakarta.

Nuriansyah, F. (2020).Efektivitas Penggunaan Media Online dalam Meningkatkan Hasil Belajar Pada Mahasiswa Pendidikan Ekonomi Saat Awal Pandemi Covid-19.Jurnal Pendidikan Ekonomi Indonesia, 1(2), 61-65.

Putrawangsa, S., \& Hasanah, U. (2018). Integrasi Teknologi Digital dalam Pembelajaran di Era Industri 4.0. Jurnal Tatsqif, 16(1), 42-54.

Rizqon Halal Syah Aji. (2020). Dampak Covid-19 pada Pendidikan di Indonesia: Sekolah, Keterampilan, dan Proses Pembelajaran. SALAM; Jurnal Sosial dan Budaya Syar-I.Vol. 7 No. 5 hlm.395-402 tahun 2020 [Online]. Available: https://doi:10.15408/sjsbs.v715.15314

Sudigdo, Sofyan. 2011. Dasar-Dasar Metodologi Penelitian Klinis Edisi ke-4. Jakarta: Sagung.

Susilo A, Rumende., C. M, Pitoyo, C.W. (2020). Coronavirus Disease 2019: Review of Current Literatures. Jurnal Penyakit Dalam Indonesia. 7(1), 45-64.

Syarifudin, Albitar S., (2020). Implementasi Pembelajaran Daring Untuk Meningkatkan Mutu Pendidikan Sebagai Dampak Diterapkannya Social Distancing.Jurnal Pendidikan Bahasa dan Sastra Indonesia. 31-33

Wati, Ega Rima. (2016). Ragam Media Pembelajaran: Visual - Audio Visual - Komputer - Power Point - Internet Interactive Video. Jakarta: Kata Pena.

Widagdo, B.W., Handayani, M., Suharto, A. 2020. Dampak Pandemi Covid-19 Terhadap Perilaku Peserta Didik Pada Proses Pembelajaran Daring Menggunakan Metode Pengukuran Skala Likert (Studi Kasus Di Kabupaten Tangerang Selatan). Jurnal Teknologi Informasi ESIT, 15(2), 63-70.

Williams, A., at.al. (2012). The impact of online lecture recordings on student performance . Australasian Journal of Educational Technology.

Yaumi, Muhammad. (2018). Media Dan Teknologi Pembelajaran. Jakarta : Prenadamedia Group.

Yuliana. (2020)., Corona Virus Disease (Covid-19); Sebuah Tinjauan Literatur. Wellness and Healthy Magazine, 2(1), 187-192.

Zhang, D., at.al. (2004). Can e-learning replace classroom learning? Communications of the ACM.https://doi.org/10.1145/986213.986216 